\title{
The emergence of John Calvin as pastoral figure from his letters
}

\begin{abstract}
Author:
Raymond Potgieter ${ }^{1}$

Affiliation:

${ }^{1}$ Department of Theology, Potchefstroom Campus, North-West University,

Potchefstroom, South Africa

Correspondence to:

Raymond Potgieter

Email:

ray@csmdist.com

Postal address:

PO Box 19492, Noordbrug

2522, South Africa

\section{Dates:}

Received: 07 Apr. 2014

Accepted: 17 July 2014

Published: 05 Nov. 2014

How to cite this article: Potgieter, R., 2014, 'The emergence of John Calvin as pastoral figure from his letters', In die Skriflig 48(1), Art. \#1829, 9 pages. http:// dx.doi.org/10.4102/ids.
\end{abstract} v48i1.1829

\section{Copyright:}

C 2014. The Authors. Licensee: AOSIS OpenJournals. This work is licensed under the Creative Commons Attribution License.
The gaunt austere figure of John Calvin portrayed in paintings is often synonymous with the view of a stern, authoritarian, dogmatic person, and a strict disciplinarian. Discovery of a more complex figure, however, awaits anyone dipping into Calvin's letters, in particular when writing pastorally to comfort, encourage, point towards hope and so forth. However, this is no second figure emerging - merely a more balanced portrait of a servant of God who has not always been fairly portrayed. This portrait must be seen as closely associated with his writings. Because theology is for the nurture and maturing of the Church and therefore cannot be divorced from it, the pastoral nature of some incidents does, however, allow the humanity of Calvin to shine through more clearly.

Johannes Calvyn: Meer as 'n sistematiese teoloog. Johannes Calvyn se skraal asketiese voorkoms soos in skilderye uitgebeeld, skep dikwels die indruk van 'n stroewe, dogmatiese en dissiplinêre figuur. Uit sy briewe en veral uit sy pastorale geskrifte blyk dit egter dat hy ' $n$ warm en gevoelvolle persoon was wat mense getroos, bemoedig en hoop gegee het. Dit is nie 'n nuwe voorstelling van Calvyn nie, maar bloot 'n meer gebalanseerde beeld van die bekende dienskneg van God wat nie altyd getrou voorgehou is nie. Trouens, hierdie getrouer beeld van hom word deur sy ander geskrifte onderskryf. Omdat teologie onder meer oor die pastorale opvoeding en opbouing van die Kerk gaan, kan daar ook met 'n oop gemoed na hierdie eienskappe van Calvyn in sy teologiese geskrifte gesoek word. Dit is juis die ontdekking van hierdie eienskappe in Calvyn se geskrifte wat daartoe bydra dat sy medemenslikheid duideliker sigbaar word.

\section{Introduction}

Here is no search or attempt at portrayal of the ideal ${ }^{1}$ pastor. There simply is no such person aside from Jesus of Nazareth. The impact of the role the Genevan consistory ${ }^{2}$ played (Calvin Inst. 4.1.8) ${ }^{3}$ can, however, not be negated, handling matters of superstition and morality for the purpose of bringing about a congregation in Geneva reflective of New Testament scriptures. The focus of personages such as Martin Luther (1483-1546) and John Calvin (1509-1564), and indeed of their followers has been by and large that of protest and reaction against the established church of the day (Bass 2012:258). It was the late Middle Ages that began to reveal symptoms of change as the discovery of knowledge came about with the novelty that persons began to read and interpret books and ideas for themselves. In particular Erasmus's Moria Enkomion 1511 and Novum Instrumentum 1516 paved the way for the reformation ${ }^{4}$ (Headlam 1912:246). This change brought about a pastoral dimension to it. Bass (Headlam 1912:173ff., cf. also pp. 173-190) says that this lead to facing fundamental questions in the quest for self: Who am I?; Where am I?; Whose am I? - implying a coming about of an awareness of the self. Questions and quest shared by Teresa of Avilla $^{5}$ (1515-1582) and John Calvin though they would mainly conclude in opposition to one another. Calvin would interpret the self as bad and Teresa as good (Bass 2012:174).

1.The doubly good creation, which included humankind, once was the ideal, which evoked divine exultation of the Creator (Potgieter 2013:203). To contrast idealism, see Plato (1992; 428/7-347 BCE), who ideally created a new republic (c. 380 BC) with citizens supposedly of just and happy dispositions the failure of which was addressed in his laws (Plato 1988; c. 360 BCE). Alternately see the striving towards the ideal Christian state in Geneva (Browning \& Witte 2005).

2.Whilst there was a symbiotic relationship established between church and the city council of Geneva concerning the exercise of discipline in Zurich (nota ecclesiae), the church left this matter mainly to the city council, giving rise to the later erastian controversy. Calvin, significantly, seldom missed the weekly meeting of the consistory: 'The Consistory provided Calvin with a laboratory to test and refine many of the theological ideas in his Institutes, commentaries, sermons, and statutes' [cursive in the original] (Witte \& Kingdon 2005:15).

3.First published in 1536 with successive publications in 1539, 1541 (French translation), 1543, 1550 and its final form in 1559 all written and published in Latin.

4.So much so that, for instance, at Oxford University two camps came about: Greeks and Trojans. The former holding to the 'New Learning' (Headlam 1912:240) and the latter of the old school of ecclesial structured authority and calling for 'sword and faggot' (p. 247).

5.Both Teresa of Avilla and Catherine of Siena (1347-1380) were named doctors of the Catholic Church by the Vatican in 1970. Though she struggled with an obdurate heart and soul, Teresa pursued her quest toward spiritual perfection (Charry 2009:418, 427). 
As a second generation reformer Calvin was part of the doctrinal awakening that found its impetus and swell during the Reformation. ${ }^{6}$ His magnum opus, in the form of the Institutes, captured the essence of a reformed systematic understanding of the scriptures. Unlike Teresa's experiential approach, ${ }^{7}$ as source of Christian authority, Calvin's continual resort was first to the scriptures and then the attempt to formulate his understanding thereof (Rowe \& Hays 2009:438) and, by implication, its experiential application. For Calvin doctrine includes experiential expression in experience, ${ }^{8}$ suggestive of being more than simply a systematic theologian. For instance, Christian living meets with sin, justification and sanctification. He (Calvin 2011) writes:

Christ was given to us by God's generosity, to be grasped and possessed by us in faith. By partaking of him, we principally receive a double grace: namely, that being reconciled to God through Christ's blamelessness, we may have in heaven instead of a Judge a gracious Father; and secondly, that sanctified by Christ's spirit we may cultivate blamelessness and purity of life. (Inst. 3.11.1)

This led to the view that Calvin's theology has no place for 'justification without sanctification or vice versa' (DeVries 2009:206). In fact doctrinal teaching is part and parcel of practical divinity and does not necessarily claim completeness. It is the attempt to elucidate those doctrines most pertinent for the 'Christian nurture and the defence of the church' (Webster 2009:4) made up of sinful individuals. This comment is significant, because it brings about a pastoral approach, which accompanied doctrinal formulations avoiding theological compositions as prized achievements alone (Webster 2009:4ff.).

This cursory sketch of the approach that Calvin is seen to have taken to theology and what emerged, was that it ought not to be seen as academic exercises in isolation, but as a continual engagement of the church with biblical truth. By implication that would therefore include the persons making up the living church, the body of Jesus Christ. In one sense one could extrapolate this and conclude that Calvin's Institutes were written for the purpose of the Church, but also to equip its author to fulfil his duties as pastor of the flock ${ }^{10}$ as effectively as possible.

This article will follow this approach and will focus particularly on $^{11}$ Calvin's letters, ${ }^{12}$ which express this

6.There is a case to be made that Calvin was introduced to the vera religio and so started to question the church's superstitions (Van 't Spijker 2009:13).

7.Religious experience here is seen from a Christian perspective, or as Charry (2009:413) states, that of Christian Theological Experience (CTE). Note the insertion of the word theological so as to claim some measure of authority.

8.See Stauffer (1971:19-31) for a brief overview of some of the skewed views about Calvin by various authors.

9.A following article will, for instance, explore the role of the Holy Spirit (Calvin 2011 Inst. 3.1.1.) and so move toward formulating the essentials of Calvin's pastora framework.

10.Calvin's writings form part of the Latin Corpus Reformatorum (Thompson 1995).

11.There is no engagement with Calvin's tracts, which are usually lumped together with his letters.

12.Although particularly referring to the early letters of Calvin (up to 1538), Augustijn et al. (2002:139) writes, 'Sometimes we ourselves were surprised how much new information came to light in a close scrutiny of the letters.' The letters cover the period May 1528 to May 1564 (Bonnet 2009:9). approach. From a selection of these letters a humane figure of Calvin will become more evident and so balance the perception of a rigid austere reformer bent upon doctrine and its purity with one who cared for people. There is, however, a caution here. Couchman and Crabb (2005:11) suggest letters are written to influence, expressing language and form for their rhetorical effect and impact upon a particular reader. ${ }^{13}$ Schaff (1984:150) did not aid the reformer's image when he wrote 'he lacked the genial element of humour and pleasantry: he was a Christian stoic: stern, severe, unbending, yet with fires of passion and affection glowing beneath the marble surface'. This accords with a 20th century view of Calvin as organiser, said to exercise tyrannical control likened to the visionary totalitarianism as exercised by Lenin (McGrath 1990:14). Bouwsma (1988:230-231) even goes as far as to discern a type of Janus identity of Calvin. One side represents a thoroughly organised individual extending to thought and deed, and the other side reveals a surprising openness to mystery, a paradox revealing his humanity. Only a few names in church history ${ }^{14}$ evoke the range from praise to curse as does that of John Calvin (Schaff 1984:157). From these comments it is clear that Calvin, the protestant reformer, is not getting much favourable press coverage. This may be addressed by discerning the reformer's pastoral approach as revealed from his letters.

\section{An introduction to the letters of John Calvin}

Calvin spent many years pastoring in Geneva (1536-1538; 1541-1564) and in Strasbourg (1538-1541). The former congregation $^{15}$ was by and large the laboratory in which he seminally practised what he believed, whilst 'the letters do give us some impression of his thoughts and aspirations' (Augustijn, Burger \& Van Stam 2002:139). His prodigious letter writing caused Warfield (1956:4; cf. Van 't Spijker 2009:150) to call him 'the great letter writer of the Reformation age'. About 3000 letters are believed to attest to his authorship. He used pseudonyms ${ }^{16}$ to preserve anonymity, some of the most famous of which is the anagram Alcuinus (Calvinus), used for the publication of the Institutes (1539) in Roman Catholic countries; Charles d'Espeville, named after a village in Angouleme in which he once stayed; Martianus Lucanius, ${ }^{17}$ whilst in voluntary exile in Basel, writing the first draft of the Institutes of Christian Religion. In fact, Calvin himself regarded his manuscripts and letters of some value. He entrusted it to his successor,

13.This statement in particular refers to general correspondence, which Couchman and Crabb (2005) identify and develop in women writing letters.

14.According to Schaff, the benchmark would be names such as Hildebrand (later pope Gregory VII), Luther, Loyola to which one could add controversial theologians such as Jacobus Arminius, Friederich Schleiermacher, Paul Tillich, Cornelius van Til, amongst others.

15.The congregation comprised of about 500 members (Van 't Spijker 2009:55).

16.Some of the known pseudonyms include Lucanius (also Lucianus), Charles d'Espeville, Depercan (Deparcau), Carolus Passelius, Joseph Calphurnius, J. de Bonneville. Most of his letters to and from the Duchess of Ferrara used the pseudonym Charles d'Espeville.

17.Van 't Spijker (2009:26) mentions that this pseudonym was used when Calvin and Louis du Tillet left France and went into voluntary exile and stayed in the suburb of St. Alban, Basel in January 1535, quoting his source in footnote 6 as 'Petrus Ramus, St. Alban, Basel in January 1535, quoting his source in footnote 6 as 'Petrus Ramus,
Basilea: Eine Rede an die Stadt Basel aus dem Jahre 1570, ed. Hans Fleig (Basel: Basilisk-Verlag, 1944), 53'. 
Theodore Beza (1519-1605) for the church ${ }^{18}$ (Bonnet 2009, vol. 4:5). According to Beza, Calvin, even on his deathbed, never abated in his care for the church. ${ }^{19}$

Augustijn et al. (2002:139-140) include prefaces and other writings as part of Calvin's correspondence. ${ }^{20}$ They trace a focus on, amongst others, Calvin as student, references to his network of friends and patrons' correspondence, his gaining support of the reformation and relationships with, amongst others, Simon Grynaeus (1493-1541), Bullinger (1504-1575) and Guillaume Farel (1489-1565).

How to glean the great reformer's pastoral approach? One could devote a study to the sermons and prayers of Calvin, his commentaries, the prefaces he wrote to his works and so reveal something of the burden for the church. ${ }^{21}$ However, Calvin's letters will serve as the primary source for this article.

The letters express the words and feelings of a pastor (Van Popta 1988), pious and devoted to his congregation. Profoundly orthodox, Calvin's praxis reveals a dynamic engagement with the Scriptures - sometimes cautious and reserved, at times outspoken and even blunt on occasion. He was a public figure whose reputation ${ }^{22}$ reached known Europe and beyond. In these letters the author is sometimes found to be wrestling with the tensions associated with duty and obligation, one who would have preferred to spend his life writing, but was not destined to do so. Some letters are personal, expressing warmth of friendship, gentle rebukes for periods of silence; others more overtly theological; and some written to august persons as letters of encouragement, making progress in the faith or pleading for one cause or another. Yet, there is always the sense of theological underpinning of each letter, sometimes more obviously so, but seldom absent. There is little of self-reflection, because his concern was always about the church, its living members, the turmoil it experienced, its leadership and a faithful understanding of the Scriptures - sufficient for all occasions. A conclusion must surely be, in this writer's opinion, that Calvin did not divorce his theology from his praxis; the tension of which is aptly put in the words of John Updike (1932-2009) in his contemporary poem Seven Stanzas at Easter (Alexander 1983:118-119):

18.Calvin apparently thought that a selection of his letters could be made available to the Reformed Churches. Bonnet's collection (2009) obviously exceeds that request. Beza published an edition of some 400 letters in 1575 . A cursory summary of the history accompanying Calvin's letters may be found in, for instance, Van 't Spijker (2009:150-150).

19.'Calvijn verloor het belang der Kerk geen "enkelen oogenblik uit het oog, en to aan zijn" laatsten ademtogt bleef hij zich zelven gelijk, al seen getrouw, volijverig dienstknecht van den Heer' (Henry 1847:417).

20.Foster (1915:574-575) mentions the immense volume of the Genevan archives 'the appalling amount of material' and of its redactors dying leaving much unfinished work and at times with evident errors.

21.For instance in Reyburn (1914:43) the point is made that Calvin was finally convinced to settle in Geneva because of the city's international influence. The implication being that, although fiercely jealous of its gained liberties (Reyburn implication being that, although fiercely jealous of its gained liberties (Reyburn 1914:45) not least expressed in moral laxity (pp. 122, 137, 337), it was a city worth ministering to for the potential it had to bring the influence of the reformation to

22.Calvin was seen by Protestant and Catholic critics alike as 'a kind of monster whose memory is enough to result in absolute recoil and rejection' (Stauffer 1971:30).
And if we will have an angel at the tomb,

Make it a real angel,

Weighty with Max Planck's quanta, vivid with hair, opaque

In the dawn light, robed in real linen

Spun on a definite loom.

Let us not seek to make it less monstrous,

For our own convenience, our own sense of beauty,

Lest, awakened in one unthinkable hour, we are embarrassed

By the miracle,

And crushed by remonstrance.

For Calvin the possibility of a living reality of faith in action, was intertwined with his belief that God was sovereignly at work in all spheres of life, seeking the coming about of a redemptive godly society. This is also clearly brought out by Stauffer (1971) and supported by McNeill (Stauffer 1971:9) 'to read at large in his letters and treatises was to encounter multiple proofs of a vivid humanness ... this aspect of his personality has been too little regarded'.

A selection of Calvin's letters will be used (Bonnet 2009), which will show firstly, his relationship to personal frailty, suffering and grief as well as to women, matchmaking and marriage, in particular his own wife, Idelette de Bure; and secondly, a glimpse into some of Calvin's friendships and mutual criticisms. ${ }^{23}$

This particular choice ${ }^{24}$ is loosely based upon Bonnet's comment (2009) regarding the purpose for publishing these letters:

Our ambition has been to make Calvin live again in his letters - to shew him as he was, with his austere and inflexible convictions, which yet were far from intolerant, in the intercourse of friendship and the freedom of the domestic circle. (p. 12; [spelling retained as in the original])

Stauffer (1971:32-93) emphasises perspectives of Calvin as husband and father, friend and pastor.

By virtue of the voluminous correspondence, the letters chosen will be merely representative of each of the relationships mentioned above. Nevertheless, they should give some indication of the human side of the reformer of Geneva challenging the unfair perception of a cold-hearted, calculating autocrat. A child of his age, Calvin's personal correspondence reveals something of the person he was. He 'must be read as a theologian and pastor, not as a political theorist and jurist' (Witte 1996:361). ${ }^{25}$ This fine balance was maintained because of a consistent lifestyle based upon the only final authority that he accepted: the Bible. Above all, it is an attempt to allow the reader to hear and see a side of John Calvin that is not customarily highlighted.

A word about referring to the letters: Witte (1996:362) sounds a wise caution in reading Calvin in that select quotations 23.1 am indebted for this insight to Augustijn et al. (2002:157).

24.I also am indebted of course to Stauffer's insights (1971).

25.To err here, according to Witte (1996:361), is to promote a cause or to follow the elaboration of Calvin's teachings by his followers. 
may be shown to support different opinions on the religious liberty he espoused. To that end there will be endeavoured as much as possible to support the arguments traced with reference to supportive sources. In references to Bonnet (2009), reference will be made to the volume and page numbers, recipient of the letter, and date or year if necessary (e.g. Bonnet 2009, vol. 4:107, to Farel 1539).

\section{Personal frailty, suffering and grief}

Calvin suffered hardships and grief at a number of levels, a topic more formally and systematically developed in the Institutes (Calvin 1957:6ff.). Bouwsma (1984:252) opines that 'A vocabulary of anxiety fills his writings' is indicative of sensitivity to experiences of others. ${ }^{26}$ It is contended that his anxiety ranged from his understanding of the unpredictable universe and, of humankind ignorant of the predictability of God and his divine attributes (Bouwsma 1984:254), to include personal frailty and sharing in the troubles and sorrows of others. For instance, whilst fleeing from France in 1534 , he and his companions were robbed by one servant and he had to loan money from another to continue the journey (Beza 1836:8-9).

When frustrated by the publication of his Institutes inconveniencing many people, Calvin exercises restraint, writing to Farel 'I do not wish to say anything more severe' (Bonnet 2009, vol. 4:104). This is interesting in that at the same time of writing, he informs Farel of his 'reasonable sorrow', mourning the death of his cousin, the Bible translator Robert Olivétan $^{27}$ (1506-1538). Friendship meant a lot to him as even his early letters testify 'Duchemin, my friend dearer to me than my life' (Bonnet 2009, vol. 4:26). Calvin expressed to Farel his anxiety about the confusion, which often accompanied his letters (Bonnet 2009, vol. 4:104-105) and the disappointment he experienced in the failures of persons he trusted to fulfil their promises. Together with Farel and Bucer, he shared in the anxiety on account of the Swiss churches (Bonnet 2009, vol. 4:227), and insightfully pleads for restraint whilst he comments 'that angry passions when once aroused must be allayed by degrees, and cannot be appeased in a single day'. Writing to Melanchthon (Bonnet 2009, vol. 5:271; cf. also pp. 270-275), he is so deeply troubled by the proclamation of the Interim in Germany that he finds difficulty to formulate his thoughts and says, 'I would have you suppose me to be groaning rather than speaking.' Calvin apparently did not enjoy travelling and was loathe engaging in lengthy church conferences or diets (Bonnet 2009, vol. 4:228, to Farel) due to his health.

The bitterness of personal grief during a visit of the plague, which deprived him of a number of friends whilst he attended meetings at Hagenau and Worms, is evident. It is

26.This comment of Bouwsma must, however, be seen in context. His article has 40 notes, but not one refers to any of Calvin's letters. In light of his article, the question is therefore raised if Calvin did not understand anxiety from a theological perspective and not so much experience it to the extent this article suggests.

27.The Waldensians funded the first French Protestant Bible, the large $5 \mathrm{~kg}$ Olivétan Bible (1535) based upon Greek and Hebrew texts and revised from time to time in the 16 th century. accompanied by his anxiety for the safety of his wife and the sick survivors of the plague:

these events have produced in me so much sadness, that it seems as if they could utterly upset the mind and depress the spirit, you cannot believe the grief which consumes me on account of the death of my dear friend Claude. ${ }^{28}$ (Bonnet 2009, vol. 4:237-238, to Farel; cf. also Stauffer 1971:41)

In spite of this state of mind, Calvin continues to involve himself in the affairs of the church, and his prayers were answered when Idellette welcomed him home to Strasbourg. This tenderness to bereavement remained with Calvin all his life. When a colleague, Jean Macar, related to Calvin by marriage (Cottret 1995:240), died, the reformer wrote to Bullinger (Bonnet 2009, vol. 7:125; cf. also pp. 124-126) that his grief extended to losing a brother in the faith and almost 'one half of my soul'. Informed of the imminent death of Viret's wife, he counsels, 'Would that I also could fly thither, that I might alleviate your sorrow, or at least bear a part of it.' Upon Viret's wife's death, Calvin invites him to Geneva to disengage his mind from grief and every other annoyance (Bonnet 2009, vol. 5:36-38, to Viret), evidencing insight into dealing with grief during a time of personal mourning. Three years later, Calvin confides in Viret that he suffers no common grief, 'I have been bereaved of the best companion of my life' and he confesses his pain and how he, through exercising self-control, manages his 'tender, or rather soft ... mind' (Bonnet 2009, vol. 5:216; cf. also pp. 216-217). Added to his care was the responsibility of raising Idelette's children from her first marriage to Jean Storder, ${ }^{29}$ a promise made to her on her deathbed. The death of his own three children in infancy was taken as cause by Catholics to pronounce it being judgement upon heretics.

Refusing to compromise and settle for a blend of Christianity and secular government, and intractable about personal holiness, Calvin and Farel were expelled from Geneva. He arrived in Strasbourg September 1538:

Perhaps no man has ever been more slandered and calumniated by the enemies of truth, nor more respected and venerated by its friends, than John Calvin. Not only have the doctrines which he taught, been grossly misrepresented and shamefully caricatured, but his life has been charged with the grossest immoralities. (Sibson 1836b:146)

Although welcome, his material lot did not improve and soon he was obliged to sell some of his books to live.

A further glimpse into Calvin's home: a housekeeper ${ }^{30}$ offended his brother, Antoine, to the extent that he stated he would not return if she remained. Calvin managed to contain his temper to such an extent that the housekeeper interpreted it as sadness and left her son behind. This caused a dilemma. To allay fears of resentment and suspicion, Calvin obliged 28.Claude Ferey, French refugee at Strasbourg' (Bonnet 2009, vol. 4:237).

29.Aka John Storder

30.Peter Daguet, a humpback, who also served as Calvin's housekeeper was eventually imprisoned for stealing from his household over many years and with whom Antoine's wife had been unfaithful (Barton 1989:121). 
himself to share meals with the son. Anxiety, however, caused Calvin to indulge in food. This upset his stomach, which he would then settle by fasting. In this instance, however, the continued intake of food caused him no little discomfort, and he suffered for the sake of his boarder (Bonnet 2009, vol. 4:204-205, to Farel). This makes all the more sense, because from his days as a student at Paris and Orleans his health suffered at the expense of commitment to his studies and lack of funds exacerbated with age and digestive complications (Walker 1906:435). Money seems to have been a constant concern for Calvin, but he was also concerned to repay his debts (Bonnet 2009, vol. 4:13, to Farel). His 'feebleness' is mentioned in writing to De Falais (Bonnet 2009, vol. 5:43; cf. also pp. 43-47), he complains to Melanchthon (Bonnet 2009 Vol. 6:482; cf. also pp. 481-485) of having been incapacitated for six weeks, suffering pain and problems due to a weak stomach. When the physicians of Montpellier went out of their way to discuss and consult one another about his physical condition, Calvin expressed his gratitude. Ever the pastor, he, in turn, referred them to his writings for 'spiritual medicine (Bonnet 2009, vol. 7:358). For Calvin there was no struggle to find a place for medical practice in the exercise of his religion, even seeing its outcome as revealing God's will, admonishing and testing obedience and trust in him without ever giving up on hope for recovery (Bonnet 2009, vol. 5:60-61, to Madame de Falais).

A glimpse into his frailty at the age of 54 is given in a letter to Bullinger (Bonnet 2009, vol. 7:362-363) complaining about respiratory and bladder problems, gout and vocal problems, and the fact that he was losing energy to conduct his business, 'insipid details'. Later that year his sufferings caused him sometimes to groan like David, 'I was silent, $\mathrm{O}$ Lord, because thou didst it', and 'Thou, Lord, bruisest me; but I am abundantly satisfied, since it is thy hand'. In the suffering for two months before his death he cried out ' $O$ Lord, how long?'31 (Beza 1836:79). His last days were spent in constant prayer, evidencing the serenity of one whose trust in God was vindicated.

From the above it is without doubt that the person behind the letters was very much one who expressed passions and frailty as much as anyone else might do. He did not try to spiritualise, or worse, deny his frailty. Instead he exercised self-control as far as possible. That he was brusque, impatient, sometimes short-tempered is not denied, but that only serves to complete the picture of one justified by faith and kept by the grace of God - a picture very unlike that of the Roman Catholic portrayal of saints.

\section{Women, matchmaking and marriage, in particular his own wife, Idelette de Bure}

Whilst regarded as humane in dealing with relationships with the opposite sex, he nevertheless 'left several key biblical passages ${ }^{32}$ on sex, marriage, and family life

31.A phrase he often uttered as he lifted his eyes to heaven even in health, because sometimes he took on the burdens of others as well as his own.

32.For instance 'Samson and Delilah, Jephthah's daughter, the Levite's concubine ... King Solomon's polygamy... Song of Solomon ... Ignored the apocrypha, which includes many relevant passages' (Witte \& Kingdon 2005:7). unexplored' (Witte \& Kingdon 2005:7). Calvin believed that marriage was firmly founded on the covenant. As it integrated all of living (Witte \& Kingdon 2005:xxv) it had to be supplemented by arguments from natural law tradition (Browning \& Witte 2005:xix). This insightful understanding (Witte \& Kingdon 2005:11) brings together the legal and the theological sides into a synergy of living inclusive of sex, marriage and family life $\mathrm{e}^{33}$ amongst others. Such a comprehensive inclusion is evident from his compassionate counselling to the suffering Madame de Rentigny (Bonnet 2009, vol. 6:381). He addresses her as 'Madame and honoured sister' (Bonnet 2009, vol. 6:383), in light of, even though in a dungeon in Paris, ${ }^{34}$ she refused the entreaties of her husband and father to renounce her protestant faith. Calvin compassionately assures her of his prayers and that her life is precious to him. He shares his insights of Satan's pitfalls, warning her of spiritual dangers. At the same time he follows up by writing a letter to the King of Navarre, telling him of the sighs and groanings of so many true believers, (that) certainly deserve to be listened to by you, and that you should take courage to come to their aid' (Bonnet 2009, vol. 6:386; cf. also pp. 384-389). His letter to Madame de Coligny (Bonnet 2009, vol. 6:468-469) follows the same desire to encourage her in her suffering by pointing out that in some sense she must regard her suffering as:

produced by God (who) has sent you this affliction only for your good and your spiritual welfare, and this consideration it is which ought to mitigate your distress, and render you patient and submissive to the will of God. (Bonnet 2009, vol. 6:468)

Calvin indirectly includes himself in the service of 'so good a Master, and submitting to so good a Father' (Bonnet 2009, vol. 6:469) through a continual reference to the inclusion of the word $u s$ in counselling the suffering woman and completes his letter, assuring her of how he will pray for her.

When a nobleman, M. de Falais, sought refuge in Geneva, Calvin soon befriended him $^{35}$ and kept a lively correspondence with him and his wife. The intimacy of Calvin's correspondence gives some evidence of the depth and emotion of his friendship with both husband and wife. See his concern in his letter (Bonnet 2009, vol. 5:60) to Ms de Falais over her husband's health, and joy at his recovery (Bonnet 2009, vol. 5:77). Whilst his former letter gently but clearly directs her thoughts to the hope of recovery, it has the added injunction that they both may not be destined to live long lives. In the latter, rejoicing at the news of De Falais' restored health, he writes, hoping that De Falais 'will feel yourself so nimbler that you will not know how to restrain your merriment, so as to make up for past time'.

33.Inclusive of all that goes with, for instance, the fullness of family life, "Most importantly, they taught the faithful how to live by the Bible's sundry teachings on sex, marriage, and family: how and whom to court, betroth, and marry; how to structure a Christian marriage and household; what to teach one's children, catechumens, and students; whether to separate, divorce, or remarry; how to catechumens, and students, whether to separate, divorce, or remarry, how to make concrete what the statutes had made cogent' (Witte \& Kingdon 2005:14).

34.Compare the letter 'To the Women detained in the prison at Paris' (Bonnet 2009, vol. 6:363-366).

35.Calvin dedicated his commentary on 1 Corinthians, on 24 January 1546 to M. de Falais (Bonnet 2009, vol. 5:29) 
Another side to Calvin, which revealed itself, was his involvement in the lives of people, especially when he thought that they needed guidance so as to honour God in their actions, ${ }^{36}$ not least in engagement and marriage (Witte \& Kingdon 2005:119ff.). This is more clearly illustrated in his efforts to facilitate relationships with the intent to matchmaking. However, despite of his most careful attempts, it seems that he did burn his fingers on more than one occasion in the process.

Marriage, from a Lutheran tradition, began with new theological principles whilst the Calvinist tradition ${ }^{37}$ developed a new law of marriage and consequent theological norms (Witte 1997:130). Central to civic life in Geneva was the consistory, which annually dealt with hundreds of diverse cases, not least family problems (Witte 1997:123ff.).

Matchmaking strained his relationship with De Falais when it seems they were at cross purposes in trying to facilitate a suitable match for the recently bereaved Pierre Viret (1511-1571). ${ }^{38}$ Viret informed Calvin of the death of his wife (Bonnet 2009, vol. 5:36-38, to Viret 1546), ${ }^{39}$ whom he married in October, 1538. It was Viret's relationship with his wife that in all probability quickened a desire for marriage in Calvin (Walker 1906:233). Misunderstandings ensued when Viret himself started looking for a suitable companion prompting Calvin to write an apology to Madame de Falais in 1546 $(19,24$ Oct.; 20 Nov.) so as to clarify the situation. About the same time, another protestant preacher, Valeran Poulain, spurned Calvin's advice, proposed marriage to Isabelle de Haméricourt, without consulting her guardian De Falias, and so soured that relationship (Witte \& Kingdon 2005:105-107). These two incidents seem to have caused Calvin to restrain the extent of further involvement in matchmaking activities (Witte \& Kingdon 2005:106).

That, however, did not stop him later from expressing strong disapproval at the upcoming marriage of Farel to Mary Torel, ${ }^{40}$ the elderly daughter of his housekeeper, people who found refuge in Neuchatel. ${ }^{41}$ Calvin voiced this publicly to the Ministers of Neuchatel (Bonnet 2009, vol. 6:473-475; cf. also p. 473) encouraging them to scandalise the marriage. It seems that Calvin appeared to have a paradigmatic expectation of Farel to live a good and pious life as a bachelor to the end of his days. The idea that an old preacher and bachelor like Farel would marry, fuel the fires of speculation although Calvin held to the highest views of marriage (Kirchhofer 1837:268-269). Cottret (1995:140) puts it like this, 'Farel, tormented by the flesh, was to marry at sixty-nine rather than burn.' The determining argument for

36. He counsels, for instance, common-sense for De Falais' sisters, something 'only those who have their wits about them' will perceive (Bonnet 2009, vol. 5:47, cf. also pp. 43-47).

37.Compare Calvin's comments in his commentary to the Ephesians 5:28-33.

38.Viret was known as 'the angel/smile of the reformation'.

39.Viret lost his two daughters and son in the plagues, which ravaged Lausanne.

40.Farel and Mary Torel got married on Tuesday, 20 December 1558. Farel was 69 years old (Bonnet 2009, vol. 6:473).

41.Spelt 'Neufchatel' (Kirchhofer 1837:270).
Calvin was the management of his household allowing him to remain devoted to his work (Cottret 1995:140).

Many of Calvin's circle of acquaintances encouraged him to marry. ${ }^{42}$ Wealth did not impress Calvin:

Concerning the marriage I shall now speak more plainly ... But always keep in mind what I seek to find in her; for I am none of those insane lovers who embrace also the vices of those they are in love with, where they are smitten at first sight with a fine figure. This only is the beauty which allures me, if she is chaste, if not too nice or fastidious, if economical, if patient, if there is hope that she will be interested about my health. (Bonnet 2009, vol. 4:141, to Farel, 1539; Schaff 1984:252; Witte \& Kingdon 2005:98)

Calvin wrote to Farel, a man he considered to be prudent when it came to entrusting him with sensitive information, of his intention to consider marriage (Bonnet 2009, vol. 4:109; cf. also pp. 107-112, 1539).

Calvin, whilst in exile from Geneva and in Strasbourg at that stage, escaped the prospect of marriage once, which he regarded as divine deliverance. At the second attempt, however, he was so sure of its contraction, he even invited Farel to officiate at the ceremony (Bonnet 2009, vol. $4: 110)$. Eventually the date was set for a Dutch widow of Gelderland, Idelette Storder de Bure ${ }^{43}$ and her children, to arrive. She lost her husband in Strasbourg during a plague. As pastor, Calvin knew both Idelette and her late husband, John. Friends pointed out her virtues changing his mind about a single life. Marriage for Calvin was a serious matter, not to be taken lightly but soberly.

In light of catholic celibacy (Cottret 1995:140), there must have been some pressure on Calvin to take a wife. He followed Bucer's advice and married at the age of 30, in August 1540. ${ }^{44}$ Robert Robinson (1726-1791) accused Calvin of marrying an Anabaptist neglecting any mention of Idelette's conversion to the reformed faith (Sibson 1836a:135).

Their home was known for its hospitality and the modest living of the family as a whole if the challenge of his meagre stipend of two hundred écus is taken into account (Walker 1906:431). Although only 31 years of age, Idelette's husband was already suffering a variety of illnesses from overwork, anxiety and lack of exercise (Walker 1906:434). After a very happy honeymoon cut short by the plague ${ }^{45}$ (Witte \& Kingdon 2005:99), she had her work cut out for her from the beginning of their marriage. She visited the sick, her home was a haven for many and she survived the plague of Geneva. In July 1542 a son was born prematurely to them and Idelette took a turn for the worse - the child

42.Marriage was not a sacrament for the church in Geneva, but symbolical of Christ's union with his church and for this life alone (Witte \& Kingdon 2005:39). He was encouraged to marry by, for instance, Farel and Bucer (Schaff 1984:252).

43.Idelette's first husband was the former Anabaptist, John Storder of Liege.

44.Stauffer (1971:33; cf. Lang 1918:39-71), however, accepts Lang's date of August $10,1539$.

45.Although accussed of maintaining a spiritual but sexless marriage, Calvin and Idelette had at least three children, none of whom survived (Witte \& Kingdon 2005:99). 
died. ${ }^{46}$ Idelette died nine years later in April 1549 when Calvin was 40 years old. From 1545 to 1549 Calvin included Idelette's name at least 30 times in his personal French correspondence (Stauffer 1971:44). Nevertheless, not even such transparency could spare him from the gossip of Libertines, such as Françoise Perrin, that Idelette had been a whore before her marriage (Barton 1989:54).

At Idelette's death bed Calvin undertook to care for her children. She responded by saying, 'I know you will not neglect what you know has been committed to God.' Nor would she insist that they be instructed in religious knowledge and the fear of God (Bonnet 2009, vol. 5:217; cf. also pp. 216-217, to Viret 1549). To the last she praised God by saying:

O glorious resurrection! God of Abraham, and of all our fathers! Not one of the faithful, who have hoped in thee for so many ages, has been disappointed: I will also hope. (Sibson 1836a:135)

Calvin was deeply moved by her 'nobleness of mind', which weighed more upon him than a 100 recommendations (Bonnet 2009, vol. 5:217; cf. also pp. 216-217, to Viret). Conscientious to a fault, Calvin amidst his grief continued to work, exercising immense self-control so as to discharge his duties (Bonnet 2009, vol. 5:216; cf. also pp. 216-217, to Viret), so that he was thought to be cold-hearted. How could he be as he continues in the same letter (Bonnet 2009):

I have been bereaved of the best companion of my life, of one who, had it been so ordered, would not only have been the willing sharer of my indigence, but even of my death. (pp. 216-217)

Here is no cold-hearted pastor, but one who contained his grief as something intimate only to be shared with his closest friends.

\section{Friendships interspersed with mutual criticisms}

Schaff (1984:151) gives a cursory overview of Calvin's relationship with the other reformers, in particular with Melanchthon, noting that they maintained 'religious harmony and personal friendship whilst maintaining their theological differences and criticisms'. Theodore Beza wrote 'in this man there was exhibited to all a most beautiful example of the life and death of the Christian' (Schaff 1984:158), but was a terror to the wicked (Beza 1836:29). Few reformers developed as many friendships and maintained them as Calvin did (Stauffer 1971:47ff.).

With Pierre Viret, ${ }^{47}$ John Calvin and Guillaume (William) Farel formed the second 'triumvirate'. ${ }^{48}$ Together these

46.In a letter to Viret (Bonnet 2009, vol. 4:344, footnote 3 ; cf also pp. 341-344) Calvin mentions the 'severe and bitter wound in the death of our infant son' as shared by himself and Idelette. Footnote 3 of the same article refers to his reply to Balduin 'God had given me a son. God hath taken my little boy. This he (Balduin) reckons up among my misdeeds, that I have no children. I have myriads of sons throughout the Christian world.

47.Viret was known as the angel of the reformation (Sheats 2012).

48.Kess (2008:1) claims that to claim the present the reformers had to repossess the past, rewrite history so as to claim a protestant legitimacy and authority in the continuation of salvation history and who better to pursue this than the 'triumvirate'. Dixon distinguishes between a first generation triumvirate, Calvin Luther and Zwingli whilst Schaff a second generation of Calvin, Viret and Farel (cf. Zuidema \& Van Raalte 2011:33). See Schaff's comparison (1984:150) with the older reformers. reformers shared in, what Stauffer (1971:57) calls, a 'brotherly friendship', also expressed in their correspondence. Walker (1906:434) mentions that whilst he had many acquaintances, his intimate friends remained few, Farel, Viret and Bullinger - noted for the voluminous correspondence they maintained. When a conversation of Calvin was distorted in its report to Bullinger, Calvin (Bonnet 2009, vol. 5:402-404) goes out of his way to assure the latter of his respect and 'brotherly attachment' and disdain of such 'offensive babbling'. He sometimes enjoyed some leisure and shared confidences with his friends, but nothing was sufficient to keep him away from his task of serving God.

When Calvin died he was 55 years old. His life was a completed work to which little could have been added if he kept on living. His death ushered in the realisation that it was now time to maintain the work he had set in motion by one more suited to the task, Theodore Beza (Walker 1906:440). It was Farel, who forced Calvin years before to consider:

You are following only your own wishes, and I declare in the name of God Almighty, that if you do not assist us in this work of the Lord, the Lord will punish you for seeking your own interest rather than his. (Beza 1836:29; Zuidema \& Van Raalte 2011:14)

The thesis that reformation theology was defined by Calvin has been debunked as it must be seen in the context of the works of other reformers, not least that of Farel (Zuidema \& Van Raalte 2011:1). Although the two did not always equate in their theology, this in no way affected their mutual affection and friendship for one another. True friendship for Calvin meant risking the test of the relationship for the sake of truth. Refusing to mitigate weakness or error, he charged Melanchthon to consider their friendship. From that basis Calvin proceeded to gently but clearly point out Melanchthon's error of conceding separation between pure doctrine and externals. This was a logical conclusion, because without any set limit to its boundaries to curb excess, the latter will ultimately unhinge itself from the former (Bonnet 2009, vol. 5:271-272; cf also pp. 270-275).

Louis du Tillet, former student at the University of Paris with Calvin, sheltered Calvin in Angoulême, because he was implicated in Nicolas Cop's denouncement as a heretic in 1533. Du Tillet followed Calvin to the continent, but was soon disillusioned by the state of the church there. This strained their personal friendship (Bonnet 2009, vol. 4:60-65, to Louis du Tillet). He denounced Calvin highlighting his many faults and questioning his call. Calvin, ever cautious, used the pseudonym Charles d'Espeville to, for instance, address Du Tillet's sincere but erroneous conception of the church and remind him of their shared and faithful walk with the Lord over many years. Nor did Calvin hesitate to admit his faults or conceal his annoyance at Du Tillet's secret departure from Geneva or his hurt in learning that Du Tillet would again embrace the Roman Catholic Faith. Although sharp at times, there was nevertheless no vindictiveness in Calvin's letter, nor did he disparage Du Tillet's decision. He merely asked his friend to reconsider his decision in light of the truth of God's Word. He did not give up on his friend. 
To Farel and Viret in his dedication of Titus (1549) Calvin (1856) writes:

I think that there has never been, in ordinary life, a circle of friends so sincerely bound to each other as we have been in our ministry ... you and I seemed to be one. (p. 276)

Here is a glimpse of the high regard Calvin placed on friendship, the duration which extended to the end of his life, spanning some 30 years and deeply impacted their respective ministries.

Some insight into his friendship with Farel shows how much Calvin valued that: ${ }^{49}$

Would that only a single opportunity were allowed me, in a familiar and confidential way, to confide to you all my hopes and fears, and in turn to hear your mind and have your help, whereby we might be the better prepared. (Bonnet 2009, vol. 4:110)

It was Farel who encouraged and supported Calvin's cousin, Robert Olivetan, in his effort to publish his French translation of the Bible at Neuchâtel (Armstrong 1992:261). On the basis of friendship Farel, Calvin's 'very excellent and righthearted brother' (Bonnet 2009, vol. 4:112), was implored by Calvin to be at his forthcoming wedding ${ }^{50}$ and to take part in its officiating 'and ask a blessing upon the marriage. I would rather have you than anyone else'. (Bonnet 2009, vol. 4:110). However, the foundation of their friendship extended to the point where Farel served as the foil that kept Calvin from being the 'infallible interpreter of (the) Word of God' (Walker 1906:430) ${ }^{51}$ without incurring the latter's wrath. The esteem with, which Calvin held Farel, is evident in his final adieu, 'Farewell, my most excellent and upright brother' (Bonnet 2009, vol. 7:364, to Farel 1564) reciprocated in Farel's letter to Fabri (Bonnet 2009, vol. 7:364, footnote 1). Shortly before his death Calvin confessed his weaknesses to the Genevan syndics, asked for their forgiveness, taking each one present by the hand (Beza 1836:90-91).

\section{Some concluding remarks}

Luther and Zwingli excite the imagination more than the memory of John Calvin, but no other reformer brought to bear his continuing influence upon the reformation and its continuance into the third millennium as he did. He did not have a charismatic personality, but, as Schaff (1984:157) puts it quaintly, 'He improves upon acquaintance.' By 1555 Calvin's position in Geneva was established. Whatever threats came, were from outside the city (Walker 1906:429). At the end of his life, in having personally witnessed the person of John Calvin for 16 years, Beza (1836) wrote:

49.Farel, highly regarded and touted as the one person to preach effectively unto reformation in France according to Gérard Roussel (1500-1550). He once exclaimed after excluding other candidates ' l know but one man fitted for such a great work; it is William Farel' (D' Aubigné 1863:499).

50.This wedding did not take place.

51.'Brother Calvin' was gradually replaced by 'Master Calvin' in Geneva, but more derogatory outside of Geneva, he was often referred to as its 'pope', 'king' and even 'calif/caliph', but in reality there was no change; he was simply one of the pastors (Walker 1906:430)
I feel myself justly warranted to declare, that in him was presented to all men, one of the most beautiful and illustrious examples of the pious life and triumphant death of a real Christian; and as it is easy for malevolence to calumniate his character, so the most exalted virtue will find it difficult to imitate his conduct. (p. 98)

To emphasise Calvin's theology and his writings at the expense of the person whose life and conduct evidentially expressed his biblical beliefs, is to miss meeting the flawed man whose claimed possession was the grace of the Lord Jesus Christ. Careful scrutiny, however, reveals a man who felt deeply, was conscious of his own physical frailty, one who sometimes was perceived to meddle in affairs to a degree not called for, who loved his wife deeply and loved his friends with equal devotion. Nevertheless, all this was subservient to the greater call of serving the Lord of the Church. To that end his person and relationship were negotiable, as they were subjected to the scrutiny of the authority of the Word of God.

\section{Acknowledgements Competing interests}

The author declares that he has no financial or personal relationship(s) that may have inappropriately influenced him in writing this article.

\section{Bibliography}

Alexander, P., (ed.), 1983, The lion book of Christian poetry with biographies by Veronica Zundel, Lion Publishing, Herts.

Armstrong, B.G., 1992, 'Pierre-Robert Olivétan', in D.K. McKim (ed.), Encylopedia of the Reformed Faith, p. 261, Westminster, John Knox Press, Louisville.

Augustijn, C., Burger, C. \& Van Stam, F.P., 2002, 'Calvin in the light of the early letters', in H.J. Selderhuis (ed.), Calvinus Praeceptor Ecclesiae: Papers of the International Congress on Calvin Research, pp. 139-157, Princeton, Droz, Internationc

Barton, F.W., 1989, Calvin and the duchess, Westminster, John Knox Press, Louisville.

Bass, D.B., 2012, Christianity after religion: The end of church and the birth of a new spiritual awakening, HarperOne, HarperCollins Publishers, New York.

Beza, T., 1836, The life of John Calvin, transl. F. Sibson, Philadelphia.

Bonnet, J. (ed.), 2009, John Calvin: Tracts and letters, vol. 4-7, transl. D. Constable, The Banner of Truth Trust, Edinburgh.

Bouwsma, W.J., 1984, 'John Calvin's Anxiety', Proceedings of the American Philosophical Society, 128(3), 252-256, September.

Bouwsma, W.J., 1988, John Calvin: A sixteenth century portrait, Oxford University Press, New York.

Browning, D.S. \& Witte, J. , 2005, 'Series preface' in J. Witte \& R.M. Kingdon, Sex, marriage, and family in John Calvin's Geneva, volume I, courtship, engagement and marriage, pp. xvii-xix, Wm. B. Eerdmans Publishing Co., Grand Rapids.

Calvin, J., 1856, Commentaries of John Calvin on the epistles to Timothy, Titus, and Philemon, transl. W. Pringle, Calvin Translation Society, Edinburgh.

Calvin, J. 1957, Institutes of Christian religion, vol. 2, transl. H. Beveridge, Wm. B. Eerdmans Publishing Co., Grand Rapids.

Calvin, J., 2011, Institutes of the Christian religion, vol. 3, transl. H. Beveridge, Pacific Publishing Studio, Seattle.

Charry, E.T., 2009, 'Experience', in J. Webster, K. Tanner \& I. Torrance (eds.), The Oxford handbook of systematic theology, pp. 413-431, Oxford University Press, Oxford.

Cottret, B., 1995, Calvin, a biography, William B. Eerdmans Publishing Company, Grand Rapids, Michigan, Cambridge.

Couchman, J. \& Crabb, A., 2005, 'Form and persuasion in women's letters, 14001700 ', in Women's letters across Europe, 1400-1700: form and persuasion, women and gender in the early modern world, pp. 3-18, Ashgate Publishing, Aldershot, England, Burlington.

D'Aubigné, J.H., 1863, History of the reformation in Europe in the time of Calvin, vol. 1 , transl. W.L.R. Gates, Longman, Roberts \& Green, London. 
DeVries, D., 2009, 'Justification', in J. Webster, K. Tanner \& I. Torrance (eds.), The Oxford handbook of systematic theology, pp. 197-211, Oxford University Press, Oxford han
Oxford.

Foster, H.D., 1915, 'John Calvin, his Life, Letters, and Work', Harvard Theological Review 8(4), 574-578, October. http://dx.doi.org/10.1017/\$0017816000009317

Headlam, C., 1912, Oxford and its story, J.M. Dent \& Sons Ltd., London.

Henry, D.P., 1847, Het leven van Johannes Calvijn, den grooten hervormer, in twee deelen, Van der Meer \& Verbruggen, Rotterdam.

Kess, A., 2008, Johann Sleidan and the protestant vision of history, Ashgate Publishing Company, Aldershot, Burlington.

Kirchhofer, M., 1837, The life of William Farel, the Swiss reformer, The Religious Tract Society, London.

Lang, A., 1918, Reformation und Gegenwart: Gesammelte Aufsätze vornehmlich zur Geschichte und zum Verstandnis Calvins und der reformierten Kirche, Menerische Hofbuchhandlung, Detmold.

McGrath, A.E., 1990, A life of John Calvin, a study in the shaping of western culture, Blackwell, Oxford.

Plato, 1988, The laws of Plato, transl. T.L. Pangle, University of Chicago Press, Chicago.

Plato, 1992, Republic, transl. G.M.A. Grube, Hackett Publishing Company, Indianapolis.

Potgieter, R., 2013, 'Divine exultation and agony in the face of evil, a creation theodicy of divine restraint' Acta Theologica 33(1), 196-213.

Reyburn, H.Y., 1914, John Calvin: His life, letters, and work, Hodder \& Stoughton, London.

Rowe, C.K. \& Hays, R.B., 2009, 'Biblical studies', in J. Webster, K. Tanner \& I. Torrance (eds.), The Oxford handbook of systematic theology, pp. 435-455, Oxford University Press, Oxford.

Schaff, P., 1984, History of the Christian church: Modern Christianity: The Swiss Reformation, vol. 8, Wm. B. Eerdmans publishing company, Grand Rapids.

Sheats, R.A., 2012, The angel of the reformation, Zurich Publishing, Tallahassee.
Sibson, F., 1836a, 'Notes to the life of Calvin', in T. Beza, The life of John Calvin, transl. F. Sibson, pp. 125-137, J. Whetham, Philadelphia.

Sibson, F., 1836b, 'The character of Calvin', in T. Beza, The life of John Calvin, transl. F. Sibson, pp. 139-226, J. Whetham, Philadelphia.

Stauffer, R., 1971, The humanness of John Calvin, transl. G. Striver, Abingdon Press, Nashville.

Thompson, J.L. 1995, 'Latin Corpus Reformatorum', in G. Baum, E. Cunitz \& E. Reuss (eds.), loannis Calvini, Opera Quae Supersunt Omnia: Calvin Opera 1-59, 18631900, Brunswick \& Berlin, Pasadena California.

Van Popta, J.L., 1988, 'John Calvin: A man of compassion', Clarion: The Canadian reformed magazine 37(20), September.

Van 't Spijker, W., 2009, Calvin: A brief guide to his life and thought, transl. L.D. Bierma, Westminster John Knox Press, Louisville.

Walker, W., 1906, John Calvin the organiser of reformed Protestantism 1509-1564, G.P. Putnam's Sons, The Knickerbocker Press, New York, London.

Warfield, B.B., 1956, Calvin and Augustine, The Presbyterian and Reformed Publishing Co., Philadelphia.

Webster, J., 2009, 'Introduction: systematic theology', in J. Webster, K. Tanner \& I. Torrance (eds.), The Oxford handbook of systematic theology, pp. 1-15, Oxford University Press, Oxford.

Witte, J., 1997, 'From sacrament to contract: marriage, religion and law in the Western tradition', in D.S. Browning \& I.S. Evison (eds.), The family, religion and culture, pp. 123, Westminster John Knox Press, Louisville.

Witte jr., J., 1996, 'Moderate Religious Liberty in the Theology of John Calvin', Calvin Theological Journal 31(1), 359-403, November.

Witte jr., J. \& Kingdon, R.M., 2005, Sex, marriage, and family in John Calvin's Geneva, volume I, courtship, engagement and marriage, Wm. B. Eerdmans Publishing Co., Grand Rapids.

Zuidema, J. \& Van Raalte, T., 2011, Early French Reform: the theology and spirituality of Guilaume Farel: St. Andrews studies in reformation history, Ashgate Publishing, Farnham. 